\title{
ISOLASI DAN IDENTIFIKASI POPULASI BAKTERI ICE NUCLEATION ACTIVE PADA JERUK KEPROK SOE DI DATARAN TINGGI MUTIS PROVINSI NUSA TENGGARA TIMUR
}

\author{
Hildegardis Missa ${ }^{1)}$ dan Anselmus Boy Baunsele ${ }^{2)}$ \\ 1.Program Studi Biologi, Fakultas Keguruan dan Ilmu Pendidikan, Universitas Katolik Widya Mandira \\ 2.Program Studi Biologi, Fakultas Keguruan dan Ilmu Pendidikan, Universitas Katolik Widya Mandira \\ 1,2Jl. Ahmad Yani No. 50-52 Merdeka-Kupang kode pos 85225 \\ E-mail: hildegardis.missa@yahoo.co.id ${ }^{1)}$ anselmusbaunsele@yahoo.co.id ${ }^{2)}$
}

\begin{abstract}
ABSTRAK
Penelitian tentang bakteri luka beku dari daerah tropis belum banyak dipublikasikan. Data-data bakteri INA yang diteliti pada Jeruk Keprok Soe di dataran tinggi Mutis ini akan memberikan informasi kebaruan bakteri INA di daerah tropis. Penelitian lanjut mengenai bakteri INA perlu dilakukan, mengingat dampak buruk bagi pertanian akibat luka beku yang disebabkan karena aktivitas ice nucleation. Tujuan dari penelitian ini adalah untuk mengetahui populasi bakteri INA, mengetahui estimasi populasi bakteri INA, uji aktivitas ice Nucleation Active dan mengetahui kelas protein INA. Pengambilan sampel tanaman Jeruk Keprok Soe menggunakan metode purposive sampling pada tiga ketinggian yaitu 2000, 2100, dan $2200 \mathrm{~m}$ dpl. Isolasi bakteri dilakukan dengan metode spread plate pada media Kings'B, aktivitas nukleasi es ditentukan dengan metode tube nucleation test. Estimasi populasi bakteri INA dilakukan dengan metode multiple-tube nucleation test formula Thomas seri 3.3.3. Hasil penelitian menunjukan bahwa populasi bakteri INA yang ditemukan pada daun jeruk keprok soe di dataran tinggi mutis tergolong tinggi yaitu $6 \times 10^{3} / \mathrm{g}$ hingga $1,2 \times 10^{4} / \mathrm{g}$ daun. hal ini menunjukkan bahwa semakin tinggi tempat maka semakin tinggi populasi bakteri INA yang ditemukan. Berdasarkan suhu pembentukan es, terdapat dua isolat bakteri, yaitu 2 sampel mengalami pembekuan pada suhu $-7^{\circ} \mathrm{C}$ dengan kelas protein INA B, sedangkan 6 sampel membeku pada suhu $-10^{\circ} \mathrm{C}$ dengan kelas protein INA C.
\end{abstract}

Kata Kunci: Isolasi, Identifikasi, Bakteri, Ice Nucleation, Jeruk Keprok

\section{PENDAHULUAN}

Bakteri merupakan mikroorganisme yang penyebarannya sangat luas dan bersifat ubiquitos, yaitu mampu hidup hampir disemua tempat (Missa, 2016). Bakteri Ice Nucleation Active (INA) merupakan bakteri yang ditemukan pada permukaan daun di dataran tinggi dengan suhu rendah (Lindo et al., 2013). Bakteri INA yang telah ditemukan antara lain : Pseudomonas syringae, Pseudomonas viridiflava, Pseudomonas Fluorescens, Erwinia hericola, dan Xantomonas campestris (Edwards et al.,2014), Pseudomonas fragi dan Pseudomonas moraviensis yang ditemukan pada permukaan daun pistachio (Rostami et al. 2018). Bakteri INA yang ditemukan ini mampu mengkatalisis pembekuan es pada suhu $-1,5^{\circ} \mathrm{C}$ sampai $-10^{\circ} \mathrm{C}$, bahkan pada suhu diatas $5^{\circ} \mathrm{C}$, dan dapat mengekspresikan protein nukleasi es dipermukaan sel sehingga suhu air menurun dan akhirnya membeku (Stephani dan Waturangi, 2012). Spesies-spesies ini, dapat menyebabkan luka beku (forst injury) di permukaan daun disebakan karena terjadinya perubahan air yang terkandung didalam sel daun menjadi es (Gurian et al., 2013).

Bakteri INA memiliki peran penting dalam biopresipitasi, dan juga dapat dimanfaatkan untuk membantu hujan dan salju dengan cara penyemaian bakteri INA pada awan sebagai pengganti penaburan garam yang sekarang telah banyak digunakan untuk membuat hujan buatan (Wahyudi, 2015). Hasil penelitian Lindow et al. (2012) menunjukan bahwa bakteri INA ditemukan pada daerah bersuhu rendah dengan suhu optimal sekitar $18-24^{\circ} \mathrm{C}$. Dataran tinggi gunung mutis memiliki ketinggian $2500 \mathrm{~m}$ dpl dan merupakan daerah terbasah di Pulau Timor, dengan suhu berkisar antara $14^{\circ} \mathrm{C}-29^{\circ} \mathrm{C}$, namun pada kondisi ektrim suhu dapat turun hingga $9^{\circ} \mathrm{C}$, sehingga memungkinkan peluang besar untuk ditemukan bakteri INA sebagai bakteri filosfer pembentukan Kristal es.

Jeruk keprok Soe merupakan kelompok tanaman yang terdapat di dataran tinggi mutis dengan kebutuhan air cukup tinggi tergantung pada curah hujan dan kelembaban udarah disekitarnya. Melihat kebutuhan air yang cukup tinggi, dan suhu di dataran tinggi mutis yang rendah diperkirakan bakteri INA juga dapat ditemukan pada tanaman jeruk keprok Soe oleh karena itu perlu dilakukan penelitian tentang isolasi dan identifikasi populasi bakteri INA dari tanaman Jerik keprok Soe di dataran tinggi Mutis, mengingat peran penting bakteri INA sebagai biopresipitasi yang bisa membentuk awan dan hujan serta masih sedikit informasi tentang bakteri INA didaerah tropis. 


\section{RUANG LINGKUP}

Dalam penelitian ini permasalahan mencakup:

1. Estimasi Populasi Bakteri Ice nucleation Active pada daun jeruk keprok soe di dataran tinggi Mutis

2. Uji aktivitas bakteri ice Nucleation active pada daun jeruk keprok soe di dataran tinggi Mutis

3. Kelas protein Ice Nucleation active bakteri INA pada daun jeruk keprok soe di dataran tinggi Mutis

\section{BAHAN DAN METODE}

Sampel tanaman jeruk keprok soe diambil di dataran tinggi mutis dengan metode purposive sampling pada tiga ketinggian yang berbeda yaitu 2000 meter diatas permukaan laut (m dpl), $2100 \mathrm{~m}$ dpl dan $2200 \mathrm{~m} \mathrm{dpl}$. Semua sampel yang diambil diberi label berdasarkan ketinggian kemudian ditempatkan dalam plastik steril dan dibawa ke laboratorium menggunakan kotak pendingin.

Isolasi bakteri dilakukan dengan mengambil 5 gram sampel daun jeruk keprok Soe kemudian direndam menggunakan $200 \mathrm{~mL}$ larutan buffer fosfat $\mathrm{pH} 7.0$ (Waturangi dan Amelia, 2009), dan dikocok pada rotary shaker selama 2 jam dengan kecepatan $150 \mathrm{rpm}$. Kemudian dilakukan pengenceran sehingga $10^{-3}$ dengan $9 \mathrm{~mL}$ aquades steril. Kemudian dari seri pengenceran, diambil 0,1 mL disebarkan pada media King's B dengan teknik cawan sebar (spread plat) dan diinkubasi pada suhu $37^{\circ} \mathrm{C}$ selama 4 x 24 jam (Missa, 2016). Media King's B dibuat dengan komposisi 20 gr protease pepton, $10 \mathrm{~mL}$ gliserol, 1,5 gr K2HPO4, 1,5 gr MgSO4.7H2O dan 15 gr agar dimasukkan ke dalam erlenmeyer kemudian ditambah $1 \mathrm{~L}$ akuades kemudian di sterilkan pada suhu $121^{\circ} \mathrm{C}$ selama 15 menit (King, 2014).

Koloni bakteri berbeda yang tumbuh di media King's B diambil dan digoreskan kembali pada media King's B agar Miring, kemudian disimpan 4-6 hari pada suhu ruang dan selanjutnya disimpan di feezer pada suhu 4$5^{\circ} \mathrm{C}$ (Stephanie \& Waturangi, 2012), untuk selanjtnya dilakukan pengujian aktivitas bakteri INA dengan menggunakan metode tube freezing yaitu memasukan $100 \mu \mathrm{l}$ suspensi bakteri berumur 4-6 hari kedalam supercool water (Lindow et al., 2013). Bakteri yang telah dimasukan kedalam supercool water didinginkan pada suhu $-5^{\circ} \mathrm{C}$ hingga $-10^{\circ} \mathrm{C}$ selama 15 menit. Bakteri INA dikelompokan menjadi tiga kelas yaitu kelas $\mathrm{A}$ membentuk inti es pada suhu $>-2^{\circ} \mathrm{C}$ hingga $-5^{\circ} \mathrm{C}$, kelas $\mathrm{B}$ membentuk inti es pada suhu $-5^{\circ} \mathrm{C}$ hingga $-7^{\circ} \mathrm{C}$, kelas $\mathrm{C}$ aktif pada suhu $-7^{\circ} \mathrm{C}$ hingga $-10^{\circ} \mathrm{C}$ (Rugless et al.,2013).

Estimasi populasi bakteri INA dilakukan dengan metodel multiple tube nucleation (Cazarlo et al., 2015), yaitu dengan cara tabung reaksi yang berisi $9 \mathrm{~mL}$ buffer fosfat steril, didinginkan pada suhu $-10^{\circ} \mathrm{C}$ selama 3 menit, kemudian tabung dikocok dan semua tabung yang mengalami pembekuan dipisahkan. Masing-masing sampel penelitian sebanyak $2 \mathrm{~g}$ dihomogenkan dalam 20 $\mathrm{mL}$ buffer fosfat, kemudian sebanyak $1 \mathrm{~mL}$ suspensi bakteri dimasukan kedalam tabung berisi buffer fosfat yang tidak membeku dan sampel yang telah dihomogenkan didinginkan pada suhu $-3^{\circ} \mathrm{C}$ sampai $-9^{\circ} \mathrm{C}$, sedangkan karakterisasi isolat bakteri dilakukan dengan pengamatan secara mikroskopis berupa pengamatan jenis gram bakteri dengan menggunakan safranin.

\section{PEMBAHASAN}

Berikut disajikan hasil dan pembahasan dari penelitian ini

\subsection{Isolat Bakteri Ice Nucleation Active pada Daun Jeruk Keprok Soe di Dataran Tinggi Mutis}

Bakteri INA yang diisolasi dari tiga stasiun ketinggian diisolasi menggunakan media King;s B yang merupakan media non-selektif dan digunakan untuk subkultur. Media ini mengandung antibiotik seperti cephalexine yang akan membuat media (King's B) cocok untuk deteksi beberapa pseudomonas seperti Pseudomonas syringae $p v$, syringae $p v$ dan Pseudomonas savastonoi hal ini yang menyebabkan koloni Pseudomonas tampak berfluoresen di media King's B (Arwiyanto et al., 2017), dan juga memberikan jumlah tertinggi unit pembentuk koloni, di beberapa lingkungan (Atlas, 2015).

Koloni bakteri yang didapatkan dari cawan kemudian dijadikan biakan murni pada media King's B. menurut Kieft dan Ruscetti (2011), biakan bakteri INA yang mememiliki aktivitas pembentukan inti es paling tinggi adalah biakan dengan usia 4-6 hari. Biakan murni yang terlalu muda ataupun terlalu tua tidak memiliki aktivitas pembentukan inti es yang tinggi. Jumlah isolat Bakteri yang didapat dari isolasi daun jeruk keprok Soe berjumlah 57 isolat, disaijkan pada tabel 1 . Semua isolat diuji aktivitas nukleasinya dengan suhu $-10^{\circ} \mathrm{C}$, selama 5 menit dan isolat yang positif bakteri INA akan membeku seperti yang terlihat pada gambar 2 .

Tabel 1. Jumlah Isolat bakteri yang didapat dari setiap stasiun pengambilan sampel

\begin{tabular}{|c|c|c|c|}
\hline $\begin{array}{c}\text { Ketinggian } \\
\text { Tempat } \\
\begin{array}{c}\text { Pengambilan } \\
\text { sampel }\end{array}\end{array}$ & $\begin{array}{c}\text { Jumlah } \\
\text { Isolat pada } \\
\text { Daun } \\
\text { Jeruk } \\
\text { Keprok Soe }\end{array}$ & $\begin{array}{c}\text { Jumlah } \\
\text { isolat } \\
\text { yang } \\
\text { positif } \\
\text { INA }\end{array}$ & $\begin{array}{c}\text { Kode } \\
\text { Isolat }\end{array}$ \\
\hline $2000 \mathrm{~m} \mathrm{dpl}$ & 21 & 2 & $\begin{array}{c}\mathrm{A} 1 \mathrm{H} 4 \\
\mathrm{~A} 4 \mathrm{H} 6\end{array}$ \\
\hline $2100 \mathrm{~m} \mathrm{dpl}$ & 20 & 2 & $\mathrm{~A} 2 \mathrm{H} 2$ \\
& & 4 & $\mathrm{~A} 2 \mathrm{H} 3$ \\
\hline $2200 \mathrm{~m} \mathrm{dpl}$ & 16 & & $\mathrm{~A} 3 \mathrm{H} 2$ \\
& & & $\begin{array}{c}\mathrm{A} 3 \mathrm{H} 4 \\
\mathrm{~A} 3 \mathrm{H} 6\end{array}$ \\
\hline
\end{tabular}

Keterangan :

A : Tempat pengambilan sampel

1 : Stasiun penelitian

$\mathrm{H} \quad$ : Nama peneliti

4 : Nomor isolat 
Tabel jumlah isolat bakteri diatas, menunjukkan bahwa pada ketinggian 2000 dan $2100 \mathrm{~m}$ dpl terdapat masing-masing 2 isolat yang positif bakteri INA dan pada ketinggian $2200 \mathrm{~m}$ dpl diperoleh 4 isolat positif bakteri INA. Berdasarkan ketinggian dan jumlah isolat yang menunjukan positif bakteri INA pada penelitian ini dikatakan unggul ketika dibandingkan dengan penelitian Latifah, (2014) pada tumbuhan lumut yang diperoleh dari jalur pendakian cemoro sewu dengan ketinggian $2026 \mathrm{~m}$ dpl, jumlah isolat positif bakteri INA adalah 2 isolat, ketinggian $2331 \mathrm{~m} \mathrm{dpl}$ diperoleh 1 isolat positif bakteri INA dan pada ketinggian $2509 \mathrm{~m}$ dpl diperoleh 4 isolat positif bakteri INA. Penelitian Yunigsih, (2015) Pada tumbuhan paku yang diperoleh dari jalur pendakian cemoro sewu pada ketinggian $2000 \mathrm{~m}$ dpl tidak ada isolat bakteri yang mempunyai aktivitas Nuklesi es ditandai dengan tidak ada isolat bakteri yang membeku, kemudian isolat yang diperoleh pada ketinggian $2100 \mathrm{~m}$ dpl terdapat 2 isolat positif bakteri INA, dan pada ketinggian $2200 \mathrm{~m}$ dpl terdapat 3 isolat positif bakteri INA.

Koloni yang dikategorikan sebagai positif bakteri INA adalah koloni yang memiliki aktivitas nucleasi es terlihat ketika suspensi koloni membeku setelah dilakukan uji aktivitas pada suhu $-10^{\circ} \mathrm{C}$ selama 5 menit. Membekunya suspensi tersebut menunjukan bahwa bakteri INA memiliki protein tunggal yang berperan dalam proses pembetukan inti es (Morris et al., 2009), sebaliknya suspensi bakteri yang tidak membeku dikategorikan sebagai negatif bakteri INA.

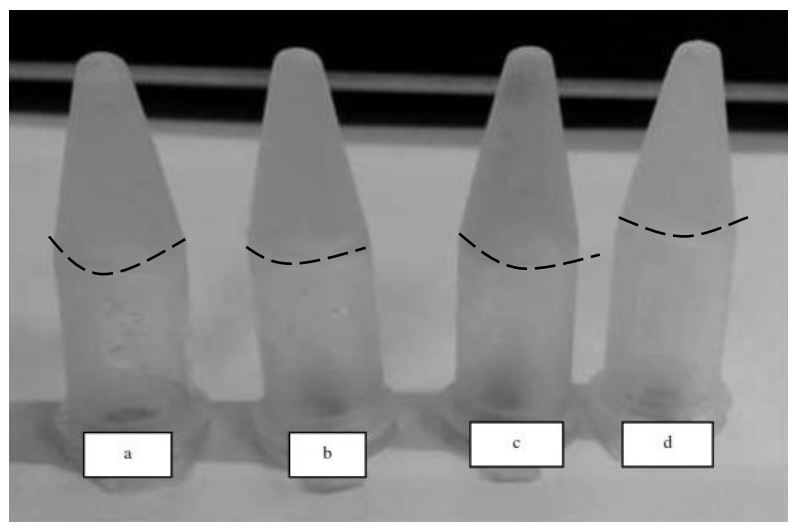

Gambar 2. Isolat yang positif bakteri INA pada daun jeruk keprok soe dalam microtobe. kode isolat (a) A3H2, (b) A3H3, (c) A3H4, (d) A3H6

Isolat bakteri INA yang positif paling banyak ditemukan pada stasiun pengambilan dengan ketinggian $2200 \mathrm{~m}$ dpl ini disebabkan karena sampel daun jeruk keprok soe yang diambil pada ketinggian $2200 \mathrm{~m}$ dpl merupakan daun yang paling banyak menyerap air hujan, mengingat bakteri INA erat kaitannya dengan air hujan. Penelitian Waturangi dan Amelia (2019), menunjukan bahwa bakteri INA berhasil diisolasi dari tanaman mengkudu (Morinda citrifolia L), Sirih (Peper betle L),
Pepaya (Carica papaya L) dan Strawberry (Fragaria X annanasa).

Pada dalam setiap stasiun pengambilan sampel terdapat beberapa bakteri yang memiliki aktivitas yang berbeda-beda, bahkan dalam 1 stasiun. Pada uji aktivitas nukleasi es yang dilakukan didapatkan hasil yaitu 2 sampel mengalami pembekuan pada suhu $-7^{\circ} \mathrm{C}$, sedangkan 6 sampel membeku pada suhu $-10^{\circ} \mathrm{C}$. Kieft dan Ruscetti (2011) menyatakan bahwa uji positif bakteri INA ditunjukkan dengan terbentuknya inti es setelah masa inkubasi 3 menit. Dilakukan pengujian pada suhu yang berbeda karena berdasarkan dari aktivitasnya, protein INA terbagi atas tiga kelas utama yaitu kelas A, aktif membentuk inti es pada suhu $-2^{\circ} \mathrm{C}$ hingga $-5^{\circ} \mathrm{C}$, Kelas B, aktif pada suhu $\geq-5^{\circ} \mathrm{C}$ hingga $-7^{\circ} \mathrm{C}$ dan Kelas $\mathrm{C}$ aktif pada suhu $\geq-7^{\circ} \mathrm{C}$ hingga $-10^{\circ} \mathrm{C}$. Berdasarkan uji yang dilakukan terdapat aktivitas nukleasi es dari isolat bakteri, ditemukan bahwa dua isolat bakteri tergolong kedalam kelas B kedua isolat ini terdapat pada stasiun pengambilan sampel dengan ketinggian 2000. M dpl dan 2100 mdpl, sedangkan enam isolat bakteri lainya merupakan kelas $\mathrm{C}$ dengan ketinggian stasiun pengambilan sampel $2000 \mathrm{mdpl}, 2100 \mathrm{~m}$ dpl dan $2200 \mathrm{~m}$ dpl.

\subsection{Estimasi Populasi Bakteri Ice Nucleation Active Pada Daun Jeruk Keprok Soe Di Dataran Tinggi \\ Mutis}

Aktivitas bakteri INA berkaitan erat dengan adanya hujan, kelembaban dan suhu udarah yang rendah, oleh karena itu perlu dilakuka uji estimasi jumlah populasi bakteri INA yang ada di permukaan daun menggunakan metode multiple tube nucleation (Cazorla et al., 2015), dan dilakukan pada suhu $-5^{\circ} \mathrm{C}$ selama 10 menit sesuai dengan pendapat Hirano et al., (2015) dan Baertlein et al., (2012) dan juga penelitian dari Cazorla et al., (2015) yang menggunakan suhu $-5^{\circ} \mathrm{C}$ sebagai suhu optimum untuk melakukan uji estimasi. Prinsip utama metode ini adalah mengencerkan sampel sampai tingkat tertentu sehingga didapat mikroorganisme yang sesuai. Jumlah populasi bakteri INA tersaji pada tabel 2 .

Tabel 2. Populasi bakteri INA pada daun jeruk keprok soe menggunakan metode MPN

\begin{tabular}{|c|c|c|c|c|c|}
\hline \multirow[t]{2}{*}{ No } & \multirow{2}{*}{$\begin{array}{c}\text { Ketinggian } \\
\text { Tempat } \\
\text { Pengambilan } \\
\text { sampel }\end{array}$} & \multicolumn{3}{|c|}{ Ulangan } & \multirow{2}{*}{$\begin{array}{l}\text { Nilai } \\
\text { MPN }\end{array}$} \\
\hline & & $10^{-1}$ & $10^{-2}$ & $10^{-3}$ & \\
\hline 1 & $2000 \mathrm{~m} \mathrm{dpl}$ & 0 & 1 & 1 & $6 \times 10^{3}$ \\
\hline 2 & $2100 \mathrm{~m} \mathrm{dpl}$ & 1 & 0 & 1 & $7 \times 10^{3}$ \\
\hline 3 & $2200 \mathrm{~m} \mathrm{dpl}$ & 0 & 2 & 2 & $1,2 \times 10^{4}$ \\
\hline
\end{tabular}

Tabel jumlah populasi bakteri INA pada daun jeruk keprok soe menunjukan bahwa populasi bakteri INA tertinggi terdapat pada daun jeruk keprok soe yang diperoleh dari ketinggian $2200 \mathrm{~m}$ dpl yaitu sebesar $1,2 \mathrm{x}$ $10^{4} / \mathrm{g}$, sedangkan populasi terendah yaitu pada daun 
jeruk keprok soe yang diperoleh dari ketinggian $2000 \mathrm{~m}$ dpl yaitu sebesar $6 \times 10^{3}$. Nilai ini menunjukan jumlah bakteri yang tinggi apabila dibandingkan dengan penelitian Karno, (2014) yang mengisolasi bakteri INA pada tumbuhan berdaun lebar dijalur pendakian cemoro sewu, gunung lawu, setelah dilakukan uji estimasi populasi, diperoleh populasi bakteri INA tertinggi yaitu $5,4 \times 10^{-3} / \mathrm{g}$, dan terendah yaitu $<3 \times 10^{-3} / \mathrm{g}$, Utami, (2015) mengisolasi bakteri INA pada tumbuhan berdaun jamur di jalur pendakian cemoro sewu, setelah diuji estimasi populasi bakteri INA menunjukan populasi tertinggi yaitu 3,6 x 10 $0^{-3} / \mathrm{g}$ dan populasi terendah yaitu < $3 \times 10^{-3} / \mathrm{g}$. Keragaman populasi tersebut dipengaruhi oleh faktor abiotik salah satunya adalah sinar matahari dan habitat yang berbeda.

\subsection{Karakterisasi Mikroskopis Isolat Bakteri INA Pada Daun Jeruk Keprok Soe}

Pengamatan mikroskopis dilakukan dengan mengamati bentuk morfologi sel dan pewarnaan gram untuk melihat jenis gram dari isolat bakteri INA tersebut. Berdasarkan hasil pewarnaan gram terhada 6 isolat bakteri positif nukleasi es menunjukan bahwa semua isolat berbentuk batang dan berwarna merah sehingga keenam isolat tersebut dikategorikan kedalam bakteri gram negatif, hal ini sesuai dengan pendapat Gurian et al., (2013) yang menyatakan bahwa hamper semua bakteri pembentuk inti es adalah bakteri gram negatif

\section{KESIMPULAN}

Kesimpulan dari penelitian ini adalah populasi bakteri INA pada daun jeruk keprok soe tergolong tinggi pada ketinggian $2200 \mathrm{~m} \mathrm{dpl} \mathrm{yaitu} \mathrm{sebesar} 1,2 \times 10^{4} / \mathrm{g}$, sedangkan populasi terendah yaitu pada daun jeruk keprok soe yang diperoleh dari ketinggian $2000 \mathrm{~m}$ dpl yaitu sebesar $6 \times 10^{3}$. Kesimpulan dari penelitian ini adalah populasi bakteri INA pada daun jeruk keprok soe tergolong tinggi pada ketinggian $2200 \mathrm{~m}$ dpl yaitu sebesar $1,2 \times 10^{4} / \mathrm{g}$, sedangkan populasi terendah yaitu pada daun jeruk keprok soe yang diperoleh dari ketinggian $2000 \mathrm{~m}$ dpl yaitu sebesar $6 \times 10^{3}$. Jumlah isolat Bakteri yang didapat dari isolasi daun jeruk keprok Soe berjumlah 57 isolat hasil uji aktivitas nukleasinya pada suhu $-10^{\circ} \mathrm{C}$, selama 5 menit, isolat yang positif bakteri INA adalah pada ketinggian $2000 \mathrm{~m}$ dpl diperoleh 2 isolat, $2100 \mathrm{~m} \mathrm{dpl} 2$ isolat dan $2200 \mathrm{~m} \mathrm{dpl} 4$ isolat.

\section{SARAN}

Saran dalam penelitian ini adalah perlu untuk dilakukan penelitian lanjutan pada tumbuhan yang lain sehingga mendapat data populasi bakteri INA yang lengkap.

\section{DAFTAR PUSTAKA}

Arwiyanto, T. 2009. Bakteri Penyebab Penyakit Tumbuhan sebagai Lawan dan sebagai Kawan. Gadjah Mada University Press, Yogyakarta.

Atlas, R. M. 2015. Handbook of Microbiological Media Fourth Edition.

Baertlein, D. A., Lindow, S. E., Panapoulos, N. J.M., Lee, S. P., Min-drinos, M. N. and Chen, T. H.H. 1992.Expression of bacterial ice nucleation gene in plants. Plant Physiology 100:1730- 1736

Cazorla, F.M., Olalla L., Tores J.A., Perez-Garcia A.,Codina J.C., and de Vicente A. 2012. A method for estimation of population densities of ice nucleation active Pseudomonas syringae in buds and leaves of mango. J.Appl. Bacteriol. 79: 341-346.

Edwars. A.R., Ronald, A., Wichman, H.A., and Orser C.S. 2014. Unusual pattern of bacterial ice nucleation gene evolution. Mol. Biol. Evol. 11:911-920.

Gurian-Sbennan, D., and Lindow S. E. 2013. Bacterial Ice Nucleation: Significance and Molecular Basis. Proc. Fla. State. Hort. Soc.J. 7:1338-1343.

Hirano, S.S., Baker, L.T., and Christian, D.U. 2015. Ice Nucleation of individual leaves in relation to populatioan sizes of ice nucleation active bacteria and frost injury. Plant. Physiol. 77:259265

Karno. R., Sutarno., and Susilowati, A. 2014. Estimasi Populasi Bakteri Ice Nucleation Active Pada Tumbuhan di Jalur Pendakian Cemoro Sewu Gunung Lawu. El-Vivo. 2:67-72.

Kieft T.L. and Ruscetti T. 2011. Characterization of biological ice nuclei from a lichen. $J$. Bacteriol.172:3519-3523.

King, E.O., Ward M.K., and Raney E.D. 2014. Two simple media for the demonstration of pyocyanin and fluorescein. Journal of Laboratory and Clinical Medicine 44: 301-307.

Latifah, N. H. 2014. Isolasi dan Estimasi Populasi Bakteri Ice Nucleation Active Pada Tumbuan Lumut di Jalur Pendakian Cemoro Sewu Gunung Lawu. Skripsi. UNS-FMIPA Jur. Biologi- M.0409042-2014

Lindow, S.E., Hirano, S.S., Barchet, W.R., Arny, D.C., and Upper, C.D. 2012. Relationship beetween ice nucleation frequency of bacteria and frost injury. Plants Physiology 70: 1090-1093.

Lindow, S.E., Arny, D.C., and Upper, C.D. 2013. Distribution of ice nucleation active on plants in nature. Appl. Environ. Microbiol. 36:831-838.

Missa, H. 2016. Isolasi Dan Karakterisasi Molekuler Gen Penyandi 16s Rrna Bakteri Selulolitik Dari Kotoran Sapi Bali (Bos Sondaicus) Di Timor 
Tengah Selatan. Tesis. UNS-Pascasarjan Prodi. Biosain- S901408004-2016

Missa, H. (2016). Diversity and phylogenetic relationship of cellulolytic bacteria from the feces of Bali Cattle in South Central Timor, East Nusa Tenggara, Indonesia. Biodiversitas, Journal of Biological Diversity, 17(2), 614-619. https://doi.org/10.13057/biodiv/d170232

Morris, C.E., Sands D.C., Bardin M., JaenickeR., VogelB., LeyronasC., Ariya P.A., and PsennerR. 2009. Microbiology and Atmospheric Processes: an Upcoming Era of Research on Bio-meteorology. Biogeosciences Discuss 5:191-212.

Rostami, Mahdieh, Nader Hasanzadeh, Pejman Khodaygan, and Ali Riahi- Madvar. 2018. "Ice Nucleation Active Bacteria from Pistachio in Kerman Province, Iran." : 51-58.

Ruggles, J.A., Marshall M.N., and Fall R. 2013. Kinetics of Appearance and Disappearance of Classes of Bacterial Ice Nucleation Support and Agregation Model for Ice Nucleus Assembly. $J$. Bacteriol. 175:7216-7221.

Stephanie, and Diana Elizabeth Waturangi. 2012. "Distribution of Ice Nucleation-Active (INA) Bacteria from Rain-Water and Air." HAYATI Journal of Biosciences 18(3): 108-12. http://dx.doi.org/10.4308/hjb.18.3.108.
Utami, A. W. 2014. Isolasi Dan Uji Aktivitas Bakteri Ice Nucleation Active Pada Tumbuhan Berdaun Jarum Di Jalur Pendakian Cemoro Sewu Gunung Lawu. El-Vivo. 3 (1):6-10

Wahyudi, A.T. 2015. Pembentukan Inti Es oleh Bakteri. Hayati 2:55-59.

Waturangi, D.E., and Amelia T. 2009. Isolation, Characterization and Genetic Diversity of Ice Nucleation Active Bacteria on Various Plants. Hayati 16 (2):54-58.

Yuningsih. 2015. Isolasi Dan Karakterisasi Bakteri INA (Ice Nucleastion Active) Pada Tumbuhan Paku di Jalur Pendakian Cemoro Sewu Gunung Lawu. Skripsi. UNS-FMIPA Jur. BiologiM0409070-2015.

\section{UCAPAN TERIMA KASIH}

Disampaikan kepada Kementrian Riset, Teknologi, dan Pendidikan Tinggi Republik Indonesia yang telah mendanai Penelitian ini pada bidang Penelitian Dosen

Pemula dengan nomor kontrak 456/WM.H9/SPKP/2019 dan Lembaga Penelitian dan Pengabdian Masyarakat (LPPM) Universitas Katolik Widya Mandira yang telah mendukung kelancaran penelitian ini. 